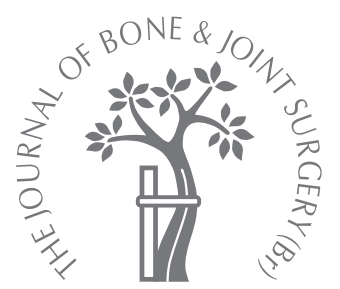

B. A. Rogers,

C. L. Murphy,

S. R. Cannon,

T. W. R. Briggs

From The Royal

National

Orthopaedic

Hospital, Stanmore, England

\title{
Topographical variation in glycosaminoglycan content in human articular cartilage
}

The weight-bearing status of articular cartilage has been shown to affect its biochemical composition. We have investigated the topographical variation of sulphated glycosaminoglycan (GAG) relative to the DNA content of the chondrocyte in human distal femoral articular cartilage.

Paired specimens of distal femoral articular cartilage, from weight-bearing and nonweight-bearing regions, were obtained from 13 patients undergoing above-knee amputation. After papain enzyme digestion, spectrophotometric GAG and fluorometric DNA assays assessed the biochemical composition of the samples. The results were analysed using a paired $t$-test.

Although there were no significant differences in cell density between the regions, the weight-bearing areas showed a significantly higher concentration of GAG relative to DNA when compared with non-weight-bearing areas $(p=0.02)$.

We conclude that chondrocytes are sensitive to their mechanical environment, and that local loading conditions influence the metabolism of the cells and hence the biochemical structure of the tissue.

Articular cartilage is a biphasic, viscoelastic, porous, permeable material with unique biomechanical properties. ${ }^{1}$ An abundant and highly complex extracellular matrix (ECM) surrounds a sparse population of chondrocytes derived from differentiated mesenchymal cells during embryonic development.

Chondrocytes comprise only $10 \%$ of the volume of articular cartilage. Their principal function is to produce and maintain the ECM. ${ }^{2}$ The latter consists of water $(65 \%$ to $80 \%)$, type-II collagen (10\% to $20 \%)$ and aggregan (complex proteoglycan molecules) and substantially dictates the inherent biomechanical properties of the cartilage.

Proteoglycans contain a protein core to which glycosaminoglycans (GAGs) are covalently bound as side-chains (Fig. 1). Each GAG molecule consists of repeating disaccharide units (chondroitin sulphate, heparan sulphate and dermatan sulphate) and carries a strong polyanionic (positive) charge which draws water into cartilage. This gives it its ability to withstand compressive forces. Its tensile properties are determined more by its collagen structure. ${ }^{3}$ Aggrecan represents more than $80 \%$ of the proteoglycans within articular cartilage (Fig. 1). It is a large aggregating molecule, with up to 100 chondroitin sulphate and
50 keratan sulphate GAG chains covalently bound to the protein core. ${ }^{1}$

Since cartilage is aneural and avascular, ${ }^{4}$ chondrocytes lack the ability to respond to neural or immune stimuli, although various environmental factors and substances may influence their metabolism including interleukins, soluble drugs and growth factors, matrix molecules, hydrostatic pressure and mechanical load..$^{5-9}$ The proteoglycan content of articular cartilage determines its resilience to compression and its viscoelastic properties.

Our study has considered the effect of mechanical load on the metabolism of chondrocytes. Regional variation in the absolute GAG content of cartilage taken from human femoral heads has been described. ${ }^{10}$ Furthermore, this variation, and consequently the amount of water held by the tissue, have been shown to influence the stiffness of cartilage. ${ }^{3}$ The concentration of chondrocytes can be quantified by a DNA assay. ${ }^{11}$ To our knowledge, there have been no previous studies of animal or human tissue which have assessed the concentration of GAGs in relation to the density of chondrocytes (DNA).

Our null hypothesis was that there was no significant difference in the concentration of 


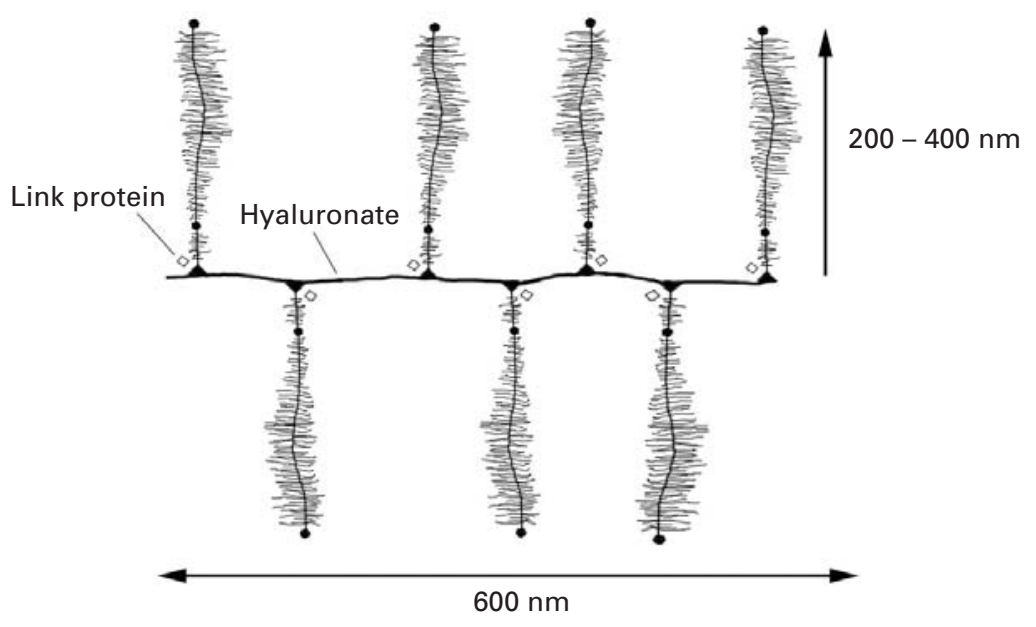

Fig. 1

Diagram of the aggrecan molecule and its binding to hyaluronate (reproduced with permission from Wright TN, et al. Proteoglycans: structure and function. In: Hay ED, ed. Cell biology of the extracellular matrix. Second ed. New York: Plenum Press, 1991:45-78).

GAGs per chondrocyte between regions of weight-bearing and non-weight-bearing human articular cartilage.

\section{Materials and Methods}

Articular cartilage was obtained from the resected distal femur of 13 patients undergoing surgery for bone or softtissue malignancy of the lower limb at The Royal National Orthopaedic Hospital, Stanmore, between October 2004 and February 2005. There were seven male and six female patients, all of whom had undergone adjuvant chemotherapy. Their mean age was 49.1 years (14 to 75$)$. The nature of the study was explained to them before surgery and written consent obtained. The study did not influence or alter their clinical management. We excluded patients with a tumour invading the knee, marked degenerative changes, evidence of large osteochondral defects, joint infection and those with previous joint surgery such as an arthroplasty or autologous chondrocyte implantation.

Full-thickness samples of articular cartilage, measuring approximately $10 \mathrm{~mm}$ x $10 \mathrm{~mm}$, were obtained immediately post-operatively using a sterile scalpel and were stored dry at $-70^{\circ} \mathrm{C}$ before biochemical assay. The medial and lateral femoral condylar summits were deemed to be weightbearing and the patellar groove and margins of the medial femoral condyle and lateral femoral condyle non-weightbearing. Each sample was identified by number to ensure that the assays were performed blind to the cartilage loadbearing status.

Digestion of cartilage. Each sample was immersed in a papain enzyme solution to dissolve the ECM. This enzyme was made by dissolving $35 \mathrm{mg}$ of L-cysteine (Sigma Chemical Co, St Louis, Missouri) in $20 \mathrm{ml}$ of phosphate-buffered EDTA (PBE) (7.1 g of $\mathrm{Na}_{2} \mathrm{HPO}_{4}, 1.86 \mathrm{~g}$ of $\mathrm{Na}_{2}$ EDTA and $500 \mathrm{ml}$ of $\left.\mathrm{H}_{2} \mathrm{O}\right)$ at $\mathrm{pH}$ 6. After syringe-filtering $(0.2 \mu \mathrm{m})$, $0.1 \mathrm{ml}$ of stock sterile papain at an activity of $35 \mathrm{U} / \mathrm{mg}$
(Worthington Biochemical Corp, Lakewood, New Jersey) was added; $1 \mathrm{ml}$ of this solution was then added to the cartilage sample in a $1.5 \mathrm{ml}$ tube, sealed with paraffin film, and placed in a water bath at $60^{\circ} \mathrm{C}$ for 16 to 18 hours for digestion. For each triplicate of cartilage analysed, a further $1.5 \mathrm{ml}$ tube contained only papain enzyme solution to act as a background control. The samples were stored at $-70^{\circ} \mathrm{C}$ until the DNA, total collagen and GAG assays were carried out. GAG assay of cartilage. A dimethylmethylene blue spectrophotometric assay ${ }^{12}$ was used to quantify the level of sulphated GAG in the papain-digested cartilage specimens. Chondroitin sulphate standards were made by diluting the working chondroitin-sulphate solution $(1 \mathrm{mg} / \mathrm{ml})$ with a PBE-cysteine solution to yield standards of $100,75,50,25$, 12.5 and $6.25 \mu \mathrm{g} / \mathrm{ml}$.

Spectrophotometric measurement of the chondroitin sulphate standards and the papain-digested cartilage samples were carried out in triplicate. Spectrophotometric measurements were taken immediately at $540 \mathrm{~nm}$ and a standard curve was obtained (coefficient of determination $\left(R^{2}\right)>0.95$ ). Next, the explants were measured in the same way.

The true sample readings were calculated by subtracting the reading for the standard papain solution from those of the cartilage samples. The GAG concentration in the cartilage samples was then obtained by comparison with the standard curve.

DNA assay in cartilage. The total DNA of the samples was quantified by fluorometric assay using the DNA-specific bisbenzimidazole dye, Hoechst 33258 (Sigma) ${ }^{11}$ by dilution of the working DNA solution $(1 \mathrm{mg} / \mathrm{ml})$, DNA standards for $6.25 \mu \mathrm{g} / \mathrm{ml}$ to $50.0 \mu \mathrm{g} / \mathrm{ml}$ were produced. Fluorometric measurement of the DNA standards and the cartilage samples was carried out in triplicate. The standards and samples were then excited at $365 \mathrm{~mm}$ with a spectrofluorometer and their emission measured over a range of $445 \mathrm{~nm}$ to $460 \mathrm{~nm}$. 
Table I. Glycosaminoglycans (GAG) concentrations ( $\mu \mathrm{g} / \mathrm{ml})$ in samples of weight-bearing and non-weight-bearing cartilage

\begin{tabular}{llcl}
\hline \multirow{2}{*}{ Sample } & \multicolumn{2}{c}{ GAG concentration weight } & per g/wet \\
\hline Weight-bearing & 418.17 & 21.82 & 0.03 \\
Non-weight-bearing & 352.12 & 18.92 & \\
\hline
\end{tabular}

Table II. Chondrocyte cell density $(\mu \mathrm{g} / \mathrm{ml})$ in weight-bearing and nonweight-bearing samples

\begin{tabular}{|c|c|c|c|}
\hline Sample & DNA concentration & Chondrocytes per $\mathbf{g}$ & p-value \\
\hline Weight-bearing & 5.889 & 30412301 & 0.89 \\
\hline Non-weight-bearing & 6.089 & 30529623 & \\
\hline
\end{tabular}

The DNA concentration was calculated by comparing the emission of the cartilage samples with that of the standard curve.

Statistical analysis. Comparative statistical analysis between pairs of cartilage explants, that is, articular cartilage taken from the weight-bearing and non-weight-bearing regions of the same patient, was performed using a paired two-tailed $t$-test (SPSS version 11.0; SPSS Inc., Chicago, Illinois). A pvalue of $<0.05$ was considered to be significant.

\section{Results}

GAG assay. The GAG concentrations $\left(\mu \mathrm{g} \mathrm{ml}^{-1}\right)$ from the paired weight-bearing and non-weight-bearing cartilage samples are shown in Table I. This shows the pooled mean from the entire series and has been calculated for both GAG concentration and total GAG $(\mu \mathrm{g})$ per wet weight of sample $(\mathrm{g})$. The results show a significantly greater $(\mathrm{p}=0.03)$ absolute GAG concentration in weight-bearing cartilage.

DNA assay. There was no statistical difference in the chondrocyte cell density assessed using the DNA assay between weight-bearing and non-weight-bearing articular cartilage ( $p>0.05$; Table II). The quantity of chondrocytes per gram of wet weight of articular cartilage was calculated by knowing that the cellular content of DNA was 7.7 picogram (pg) per chondrocyte, a figure also derived by fluorometric assay. ${ }^{11}$

Combined assay. The weight of GAG per chondrocyte was calculated by dividing the weight of GAG per $\mu \mathrm{g}$ by the cellular density determined by the DNA assay. When compared with the pooled mean of the entire series there was a significantly higher GAG per DNA ( $\mathrm{p}=0.02)$ in the weightbearing cartilage (Fig. 2).

The amount of GAG present per chondrocyte was calculated using the figure of $7.7 \mathrm{pg}$ of DNA per chondrocyte. ${ }^{11}$ Figure 3 details paired explants taken from individual limbs, and except for one pair, there is a significantly higher $(\mathrm{p}=0.02)$ quantity of GAG per chondrocyte in the weightbearing cartilage.

The mean ratio of GAG $(\mu \mathrm{g})$ per $\mu \mathrm{g}$ of DNA in weightbearing regions compared with non-weight-bearing regions was 1.78 (0.9 to 6.2) indicating that chondrocytes from weight-bearing regions contained, on average, 1.78 times

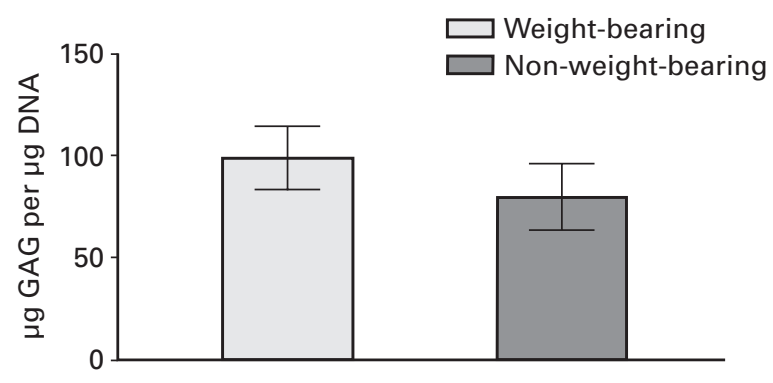

Fig. 2

Bar chart showing the total glycosaminoglycan (GAG) $(\mu \mathrm{g})$ per DNA $(\mu \mathrm{g})$ in weight-bearing and non-weight-bearing cartilage $(p=0.02$ $\mathrm{N}=13$ ).

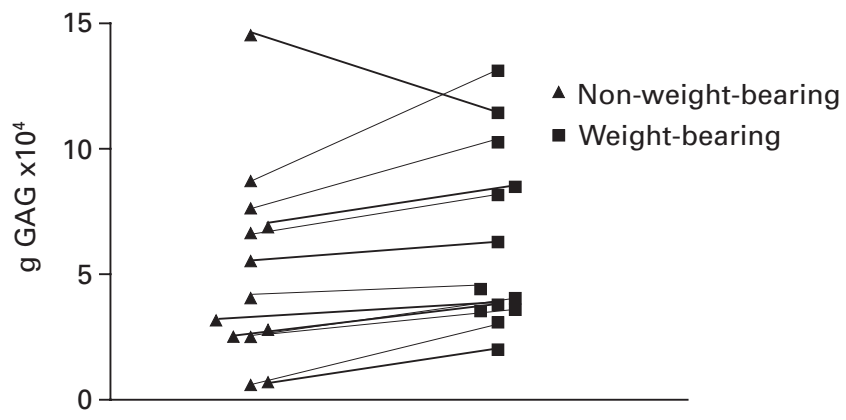

Fig. 3

The amount of glycosaminoglycan (GAG) present per chondrocyte in patient-paired explants $(p=0.02, N=13)$.

more GAG in their ECM than those from non-weight-bearing regions.

\section{Discussion}

A number of studies have demonstrated the importance of physiological loading on the biology of chondrocytes,13-15 and the metabolic response of cartilage to loading. ${ }^{5-9,13,15-20}$ Variations in the proteoglycan content of cartilage in different sites have been shown in both animal and human studies. ${ }^{18,21-23}$ These considered the absolute concentration of proteoglycan in cartilage without relating it to chondrocyte density. By contrast, our study has compared the quantity of sulphated GAG present per chondrocyte from different regions of the femoral articular surface of the human knee.

The results obtained from the GAG and DNA assays in our study compare well with those of previous human and animal studies ${ }^{2,11,12,23}$ despite the fact that the cartilage samples came from patients who had undergone chemotherapy. While our study demonstrated no significant difference in chondrocyte density between weight-bearing and non-weight-bearing cartilage, there was on average 1.78 times more GAG in load-bearing articular cartilage $(\mathrm{p}=$ $0.0004)$. On average there was 1.78 times more GAG per chondrocyte in weight-bearing locations $(\mathrm{p}=0.02)$. These 
results refute the null hypothesis and suggest that significant differences in GAG concentration must relate to differences in the metabolism of chondrocytes rather than in their density.

Animal studies have indicated that decreased weightbearing affects both the thickness ${ }^{21,24,25}$ and GAG concentration of cartilage..$^{20,26}$ The variation in thickness of articular cartilage from the human knee has been mapped using cadaver tissue $^{27}$ and by arthrography. ${ }^{28}$ The high loads transmitted through the patellofemoral joint and the resulting thick retropatellar articular cartilage support the theory that cartilage is modelled in response to mechanical load. ${ }^{29,30}$ Our findings confirm those of previous human tissue studies which have quantified the absolute proteoglycan levels from different sites in the knee. ${ }^{23}$

Our study has added to the evidence linking the physical forces exerted upon chondrocytes, through the ECM to their metabolic activity by a mechanism termed mechanotransduction. ${ }^{5,6}$ This involves cellular, molecular and genetic pathways leading to some form of altered gene expression. ${ }^{15,16,18,19,22}$ The integrin family of dimeric transmembrane proteins are considered to be the principal vehicle of the cell/matrix interaction. ${ }^{31}$ This triggers a plethora of intracellular pathways which alter gene expression, thus modifying both the biosynthesis and biodegradation of the ECM. These gene products include the following: 1) ECM proteins (collagens and aggrecan); 2) growth proteins regulating one cell cycle (cyclins and Cdks); 3) cytokines (interleukin-1, -4 and -5 ); 4) growth factors (transforming growth factor beta, fibroblast growth factor); 5) matrix metalloproteinases and tissue inhibitors of metalloproteinase; and 6) angiogenic and anti-angiogenic factors (troponin and chondromodulin).

Autologous chondrocyte implantation is a new and evolving technique which is used to treat symptomatic defects of articular cartilage especially in young adults. ${ }^{32-34}$ Non-weight-bearing cartilage is cultured after enzymatic degradation, and implanted into the chondral defect in a load-bearing region. The biochemical response of previously non-load-bearing chondrocytes, cultured and transposed into load-bearing regions, has yet to be clarified or correlated with the clinical response and is of interest given the results of our study. Studies are required to determine whether implanted chondrocytes respond to their new mechanical environment by altering gene expression and consequently the surrounding ECM.

In summary, our findings have shown that there is no significant difference in chondrocyte density between weightbearing and non-weight-bearing regions of human articular cartilage and that human articular cartilage in weightbearing regions contains significantly more sulphated GAG than that in non-weight-bearing regions, in both absolute terms and in the individual cell. We conclude that human chondrocytes are sensitive to their mechanical environment, and that local loading influences the metabolism of the cells, and hence the biochemical structure of the tissue.
No benefits in any form have been received or will be received from a commercial party related directly or indirectly to the subject of this article.

\section{References}

1. Mankin HJ, Mow VC, Buckwalter JA. Articular cartilage structure, composition and function. In: Buckwalter JA, Einhorn TA, Simon WH, eds. Orthopaedic basic science. AAOS 2005;444-67.

2. Armstrong SJ, Read RA, Price R. Topographical variation within the articular cartilage and subchondral bone of the normal ovine knee joint: a histological approach. Osteoarthritis Cartilage 1995;3:25-33.

3. Kempson GE, Muir H, Swanson SA, Freeman MAR. Correlations between stiffness and the biochemical constituents of cartilage on the human femoral head. Bio chim Biophys Acta 1970;215:70-7.

4. Ross MH, Romrell LJ. Cartilage, histology: a text and atlas. Williams \& Wilkins, 1989:123-38.

5. Parkkinen JJ, Lammi MJ, Helminen HJ, Tammi M. Local stimulation of proteoglycan synthesis in articular cartilage explants by dynamic compression in vitro. $J$ Orthop Res 1992;10:610-20

6. Sah RL, Kim YJ, Doong JY, et al. Biosynthetic response of cartilage explants to dynamic compression. J Orthop Res 1989;7:619-36.

7. Slowman SD, Brandt KD. Composition and glycosaminoglycan metabolism of articular cartilage from habitually loaded and habitually unloaded sites. Arthritis Rheum 1986;29:88-94.

8. Stoltz JF. Adaptation concept, tissue remodeling, mechanobiology and tissue engineering: a survey. Biorheology 2004;41:155-6

9. Torzilli PA, Grigiene R, Huang $\mathbf{C}$, et al. Characterization of cartilage metabolic response to static and dynamic stress using a mechanical explant test system. J Bio mech 1997:30:1-9.

10. Maroudas A, Evans H, Almeida L. Cartilage of the hip joint: topographical variation in glycosaminoglycan content in normal and fibrillated tissue. Ann Rheum Dis 1973;32:1-9.

11. Kim YJ, Sah RL, Doong JY, Grodzinsky AJ. Fluorometric assay of DNA in cartilage explants using Hoechst 33258. Anal Biochem 1988;174:168-76.

12. Farndale RW, Sayers CA, Barrett AJ. A direct spectrophotometric microassay for sulfated glycosaminoglycans in cartilage cultures. Connect Tissue Res 1982:9:247-8.

13. Gray ML, Pizzanelli AM, Grodzinsky AJ, Lee RC. Mechanical and physiochemica determinants of the chondrocyte biosynthetic response. J Orthop Res 1988;6:777-92

14. Gray ML, Pizzanelli AM, Lee RC, Grodzinsky AJ, Swann DA. Kinetics of the chondrocyte biosynthetic response to compressive load and release. Biochim Biophys Acta 1989;991:415-25.

15. Larsson T, Aspden RM, Heinegard D. Effects of mechanical load on cartilage matrix biosynthesis in vitro. Matrix 1991;11:388-94.

16. Blain EJ, Gilbert SJ, Wardale RJ, et al. Up-regulation of matrix metalloproteinase expression and activation following cyclical compressive loading of articular cartilage in vivo. Arch Biochem Biophys 2001;396:49-55.

17. Bonassar LJ, Grodzinsky AJ, Frank EH, et al. The effect of dynamic compression on the response of articular cartilage to insulin-like growth factor-l. J Orthop Res 2001;19:11-17.

18. Burton-Wurster N, Vernier-Singer M, Farquhar T, Lust G. Effect of compressive loading and unloading on the synthesis of total protein, proteoglycan, and fibronectin by canine cartilage explants. J Orthop Res 1993;11:717-29.

19. Buschmann MD, Hunziker EB, Kim YJ, Grodzinsky AJ. Altered aggrecan synthesis correlates with cell and nucleus structure in statically compressed cartilage. J Cell Sci 1996;109(Pt 2):499-508.

20. Kiviranta I, Jurvelin J, Tammi M, Saamanen AM, Helminen HJ. Weight bearing controls glycosaminoglycan concentration and articular cartilage thickness in the knee joints of young beadle dogs. Arthritis Rheum 1987;30:801-9.

21. Bullough PG, Yawitz PS, Tafra L, Boskey AL. Topographical variations in the morphology and biochemistry of adult canine tibial plateau articular cartilage. J Orthop Res 1985:3:1-16.

22. Kim YJ, Sah RL, Grodzinsky AJ, Plaas AH, Sandy JD. Mechanical regulation of cartilage biosynthetic behavior: physical stimuli. Arch Biochem Biophys 1994;311:112

23. Bjelle A. Content and composition of glycosaminoglycans in human knee joint cartilage: variation with site and age in adults. Connect Tissue Res 1975;3:141-7.

24. Kincaid SA, Van Sickle DC. Regional histochemical and thickness variations of adult canine articular cartilage. Am J Vet Res 1981;42:428-32

25. Kiviranta I, Tammi M, Jurvelin J, et al. Articular cartilage thickness and glycosaminoglycan distribution in the young canine knee joint after remobilization of the immobilized limb. J Orthop Res 1994;12:161-7.

26. Kostenszky KS, Okah EH. Effect of increased functional demand on the glucosaminoglycan (mucopolysaccharide) content of the articular cartilage. Acta Biol Acad Sci Hung 1972;23:75-82. 
27. Terukina M, Fujioka H, Yoshiya S, et al. Analysis of the thickness and curvature of articular cartilage of the femoral condyle. Arthroscopy 2003;19:969-73.

28. Hall FM, Wyshak G. Thickness of articular cartilage in the normal knee. J Bone Joint Surg [Am] 1980;62-A:408-13.

29. Ficat C, Aroudas A. Cartilage of the patella: topographical variation of glycosaminoglycan content in normal and fibrillated tissue. Ann Rheum Dis 1975;34:51519.

30. Ficat RP, Hungerford DS. Disorders of the patello-femoral joint. Baltimore: Williams and Wilkins, 1977.
31. Millward-Sadler SJ, Salter DM. Integrin-dependent signal cascades in chondrocyte mechanotransduction. Ann Biomed Eng 2004;32:435-46

32. Brittberg M, Peterson L, Sjogren-Jansson E, Tallheden T, Lindahl A. Articular cartilage engineering with autologous chondrocyte transplantation: a review of recent developments. J Bone Joint Surg [Am] 2003;85-A(Suppl 3):109-15.

33. Minas T, Chiu R. Autologous chondrocyte implantation. Am J Knee Surg 2000;13:4150.

34. Peterson L, Minas T, Brittberg M, et al. Two- to 9-year outcome after autologous chondrocyte transplantation of the knee. Clin Orthop 2000;374:212-34. 